J. Amer. Soc. Hort. Sci. 115(2):281-287. 1990.

\title{
Comparison of Cell Wall Components in Normal and Disordered Juice Vesicles of Grapefruit
}

\author{
Yong-Soo Hwang ${ }^{1}$ \\ Citrus Research and Education Center, IFAS, University of Florida, 700 Experiment Station Road, \\ Lake Alfred, FL 33850 \\ D.J. Huber \\ Vegetable Crops Department, IFAS, University of Florida, Gainesville, FL 32611
}

L.G. Albrigo

Citrus Research and Education Center, IFAS, University of Florida, 700 Experiment Station Road, Lake Alfred, FL 33850

Additional index words. pectins, hemicelluloses, cellulose, Citrus paradisi

Abstract. Cell wall composition and structure were examined in visually normal (N), granulated (G), and collapsed (VC) juice vesicles of 'Marsh Seedless' grapefruit (Citrus paradisi) Macf.). According to gel-filtration data, VC appeared to be associated with a modification of water-soluble (WSP) and chelate-soluble (CSP) pectin molecular weight $\left(M_{r}\right)$; small-M $M_{r}$ pectins increased, whereas large-J4. pectins decreased. The difference in $M_{z}$ of pectins did not appear to be mediated by polygalacturonases. Molecular weight of hemicelluloses did not differ. Granulated vesicles contained about two times more structural polysaccharides (pectins, hemicelhdose, and cellulose) than $\mathbf{N}$ vesicles, although hemicellulose and pectin $M_{z}$ modification were absent. Ion-exchange profiles of WSP, CSP, and hemicelhrlose fractions of $\mathrm{VC}$ and $\mathrm{G}$ vesicles were not different from those of $\mathrm{N}$ vesicles. Individual cells in vesicles with $\mathrm{G}$ and these vesicles themselves were much larger than those of $\mathrm{N}$ vesicles, whereas cells in VC were partially or completely collapsed.

According to Bartholomew et al. (1941), juice-vesicle disorders in citrus were recognized in the early 1900s. Two basic types of disorders have been distinguished in the literature: a hardening of the vesicles followed by partial dehydration (gran-

Received for publication 6 June 1989. Florida Agricultural Experiment Station Journal Series no. 9898. This report is work done as partial fulfillment of the $\mathrm{PhD}$ requirement at the Univ. of Florida. The cost of publishing this paper was defrayed in part by the payment of page charges. Under postal regulations, this paper therefore must be hereby marked advertisement solely to indicate this fact.

'Present address: Dept. of Horticulture, Chungnam National Univ., Daejeon, South Korea. ulation; G) and the complete collapse of vesicles (vesicle collapse; VC) (Bartholomew et al., 1941; Albrigo et al., 1980). Depending on the fruit and location within the fruit where VC has been found, several names have been used in the literature to describe VC: dry juice sac (Bartholomew et al., 1941), core dryness (Noort, 1969), blossom-end G and stylar-end G (Bartholomew et al., 1941), and VC (Albrigo et al., 1980). We found no detailed studies of these VC disorders, although $\mathrm{G}$ has been studied extensively.

Hardening and enlarged juice vesicles are characteristic of G (Bartholomew et al., 1941). Granulation reduces fruit quality due to a decrease in sugar and acid content (Awasthi and Nau- 
riyal, 1972; Bartholomew et al., 1941; Chakrawar and Singh, 1977a, 1977b; E1-Zeftawi, 1973, 1978; Gilfillan and Stevenson, 1977; Matsumoto, 1964; Sinclair and Jolliffe, 1961). Granulated vesicles contain more ethanol-insoluble solids (EIS) (Sinclair and Jolliffe, 1961), which are largely composed. of cell walls (Bartholomew et al., 1941), than do N vesicles. Among the cell-wall components, pectins in particular have been proposed to be a potential factor associated with the hardening of $G$ vesicles through gelation (Bartholomew et al., 1941; Sinclair and Jolliffe, 1961). However, no studies have been conducted to compare detailed changes in these and other cell-wall components of $\mathrm{G}$ vesicles.

Both G and VC occur in grapefruit, but usually VC occurs more commonly than G (Hwang et al., 1988). Since visible symptoms of VC differ from G, we thought that VC in grapefruit might occur via a mechanism unlike that responsible for G. The present study focused on comparing the biochemical differences characteristic of G and VC in grapefruit, especially regarding the structural and compositional features of cell-wall polysaccharides, to see if similarities existed between the two vesicle disorders.

\section{Materials and Methods}

Plant materials. Visually normal and disordered juice vesicles were isolated from disordered 'Marsh Seedless' grapefruit at harvest or from fruit stored at $21 \mathrm{C}$ and $90 \%$ to $95 \% \mathrm{RH}$ for 40 days. Adjacent juice vesicles that showed no visible symptoms of $\mathrm{G}$ or $\mathrm{VC}$ were regarded as $\mathrm{N}$ vesicles for comparison. A seasonal study from August to March (unpublished data) indicated that no major EIS or wall structural component changes occurred in juice vesicles in healthy nondisordered fruit. Vesicles were placed in an ice bath as they were isolated and were quickly frozen at $-40 \mathrm{C}$ and then stored in polyethylene bags at $-20 \mathrm{C}$. Each replication, usually three, of vesicles for a given disorder and its adjacent apparent normal vesicles was collected from fruit of the same harvest date and grove source. Standard deviations are presented for the values in these paired comparisons.

Preparation of ethanol insoluble solids. Ethanol-insoluble solids were prepared basically as described by Huber (1984), with slight modification. Vesicle tissue (45 g) was homogenized in $190 \mathrm{ml} \mathrm{95 \%} \mathrm{ethanol} \mathrm{for} 3 \mathrm{~min}$. The homogenate was refluxed for $20 \mathrm{~min}$ in a boiling water bath and then stored overnight at $-20 \mathrm{C}$. The suspension was filtered through Miracloth (Biochemical Corp., La Jolla, Calif.) and washed with $250 \mathrm{ml}$ of $80 \%$ ethanol $(\mathrm{v} / \mathrm{v})$, followed by $250 \mathrm{ml}$ of $80 \%$ acetone $(\mathrm{v} / \mathrm{v})$ and $400 \mathrm{ml}$ of $100 \%$ acetone. After evaporating the excess acetone, EIS were dried overnight at $35 \mathrm{C}$ and stored in a desiccator at room temperature.

Determination of total pectins and cellulose. Total polyuronides in EIS were measured by the method of Ahmed and Labavitch (1977). Chilled sulfuric acid $(2.5 \mathrm{ml})$ was added to 5 to $6 \mathrm{mg}$ EIS in an ice bath. After each of two 5-rein intervals, $0.7-\mathrm{ml}$ aliquots of deionized (DI) water were added and the suspensions were stirred. After an additional 5 rein, $35 \mathrm{ml}$ of DI water were added and aliquots $(0.5 \mathrm{ml})$ analyzed for total uronic acid sugar content (Blumenkrantz and Asboe-Hanson, 1973). Cellulose content in EIS was determined as described by Updegraff (1969). Twenty milligrams of EIS were placed in $5 \mathrm{ml}$ of 4 acetic acid :1 nitric acid $: 2 \mathrm{H}_{2} \mathrm{O}$ (by volume) and placed in a boiling water bath for $30 \mathrm{~min}$. The suspension was centrifuged in a clinical centrifuge for $10 \mathrm{~min}$ at $490 \mathrm{x} \mathrm{g}$. The pellet was washed with $10 \mathrm{ml}$ of DI water $(2 \times)$ and centrifuged. The pelleted material was then transferred to $67 \%$ sulfuric acid and maintained at room temperature for $1 \mathrm{hr}$. The hydrolysate was diluted by transferring to $25 \mathrm{ml}$ of distilled water. Total hexoses were measured by the anthrone procedure (Hedge and Hofreiter, 1962).

Isolation and determination of soluble polyuronides and hemicelluloses. Water-soluble pectins (WSP) were isolated by suspending EIS (100 mg) in $35 \mathrm{ml}$ of DI water. The suspension was placed on a shaker for $6 \mathrm{hr}$ at room temperature. After 6 $\mathrm{hr}$, the suspension was filtered through Miracloth and washed with $10 \mathrm{ml}$ of DI water. The combined filtrates were further filtered through glass-fiber filters (Whatman G/FC) under aspiration. The filtrates were stored at $-20 \mathrm{C}$ until used. After extraction of water-soluble polyuronides, chelator-soluble pectins (CSP) were extracted by placing the recovered powder in $35 \mathrm{ml}$ of Na-acetate $\left(40 \mathrm{mM} \mathrm{pH} 5.0\right.$ ) containing $20 \mathrm{mM} \mathrm{Na}_{2}$ EDTA. The subsequent methods were as described for WSP.

Before extraction of hemicelluloses, polyuronides were removed from the EIS by placing $100 \mathrm{mg}$ of EIS in $150 \mathrm{ml}$ of Na-phosphate (100 mM, pH 6.5) containing $20 \mathrm{~mm} \mathrm{Na}$ EDTA. The suspension was then placed in a boiling water bath for 30 min. Afterwards, the suspension was filtered through Miracloth, washed with $150 \mathrm{ml}$ of extraction buffer, followed by $500 \mathrm{ml}$ of DI water. Hemicelluloses were extracted by suspending the residual powder in $15 \mathrm{ml}$ of $4 \mathrm{~N} \mathrm{NaOH}$ containing $6 \mathrm{mg} \mathrm{NaBH} /$ ml. After two successive 4-hr extractions, the alkali-soluble fractions were filtered through Miracloth. The combined filtrates were neutralized with concentrated acetic acid and dialyzed against running tap water $(12 \mathrm{hr}$, room temperature), 4 liters of $10 \%$ methanol $(2 \times 12 \mathrm{hr}, 4 \mathrm{C})$, and finally with 4 liters of DI water $(2 \times 12 \mathrm{hr}, 4 \mathrm{C})$. The dialyzed samples were filtered through GF/C filter paper. The filtrates were stored at - 20C. Sugar content of the alkali extracts was measured by the phenol-sulfuric acid method (Hedge and Hofreiter, 1962) using D-galactose as the standard.

Gel-filtration chromatography of soluble polyuronides and hemicelluloses. Gel-filtration of polyuronides was conducted on a bed $(60 \mathrm{~cm}$ long $\times 1.5 \mathrm{~cm}$ wide) of Ultrogel AcA 22 (BioRad, Richmond, Calif.) packed in Na-acetate buffer $(25 \mathrm{~mm}$, $\mathrm{pH}$ 5.0) containing $3 \mathrm{~mm} \mathrm{Na}_{2}$ EDTA and $100 \mathrm{~mm} \mathrm{NaCl}$. About $2 \mathrm{mg}$ polyuronide in $2 \mathrm{ml}$ of extraction medium (water or buffer) were applied to the column and eluted at a flow rate of 17.5 $\mathrm{ml} \cdot \mathrm{cm}^{-2} \cdot \mathrm{hr}^{-1}$. Aliquots $(0.5 \mathrm{ml})$ of the $2-\mathrm{ml}$ fractions were analyzed for total uronic acid content (Blumenkrantz and AsboeHanson, 1973).

Hemicelluloses $(\approx 4 \mathrm{mg}$ ) in $2 \mathrm{ml}$ of the $30 \mathrm{mM}$ acetate buffer were applied to a bed $(60 \mathrm{~cm}$ long $x 1.5 \mathrm{~cm}$ wide) of Ultrogel AcA 34 operated in the same buffer system. Hemicelluloses were eluted at a flow rate of $63 \mathrm{ml} \cdot \mathrm{cm}^{-2} \cdot \mathrm{hr}^{-1}$. Fractions of 2 $\mathrm{ml}$ were collected and $0.5-\mathrm{ml}$ aliquots were assayed for hexose by the phenol-sulfuric acid procedure.

Ion-exchange chromatography. Samples were subjected to ion-exchange chromatography before neutral sugar analysis of polyuronides. Ion-exchange chromatography was carried out on a bed $(16 \mathrm{~cm}$ long $\times 1.5 \mathrm{~cm}$ wide) of DEAE-Sephadex (Sigma, St. Louis) that was equilibrated and packed in Na-phosphate buffer (15 mM, pH 6.8) containing $20 \mathrm{~mm} \mathrm{NaCl}$ and $5 \mathrm{~mm} \mathrm{Na}_{2}$ EDTA. Following dialysis (Spectrapor 2000) against the column buffer, $8 \mathrm{mg}$ of polyuronides were applied. After $100 \mathrm{ml}$ of starting buffer was collected, the column was step-eluted with the same buffer containing $0.5 \mathrm{M} \mathrm{NaCl}$. Polyuronides eluted by $0.5 \mathrm{M} \mathrm{NaCl}$ were recovered and then dialyzed against DI water for $24 \mathrm{hr}$ at $4 \mathrm{C}$. Higher $\mathrm{NaCl}$ concentrations eluted no additional pectin. 
Neutral sugar analysis. Polyuronide $(1 \mathrm{mg})$ was air-dried in Reacti-Vials (Pierce Chemical Co., Rockford, Ill.) and hydrolyzed and acetylated as described by Loescher and Nevins (1972). For compositional analyses of hemicelluloses, $\approx 8 \mathrm{mg}$ was applied to the DEAE-Sephadex column operated as described above. Polymers recovered in the column wash (unbound) were collected and subjected to hydrolysis and acetylation. The derivatized neutral sugars were examined by gas chromatography on a glass column packed with 3\% SP 2340 (Supelco, Bellefonte, Pa.).

Polygalacturonase extraction and assay. Partially thawed vesicle tissue (15 g) was homogenized for $3 \mathrm{~min}$ in $15 \mathrm{ml} \mathrm{Na}$ phosphate buffer (200 mM, pH 6.0) containing $2.4 \mathrm{~m} \mathrm{NaCl}$. After centrifugation $(20 \mathrm{~min}$ at $32,000 \times \mathrm{g}$ ), proteins were precipitated from the supernatant by adding solid ammonium sulfate to $75 \%$ saturation. The precipitated protein was centrifuged for $20 \mathrm{~min}$ at $32,000 \times \mathrm{g}$. The pellet was dissolved in $2.5 \mathrm{ml}$ of Na-acetate buffer ( $50 \mathrm{~mm}, \mathrm{pH} 5.0)$ and desalted by passing through a PD-10 column packed with Sephadex G-25M (Sigma). Protein content was determined calorimetrically as described by Bradford (1976) using bovine serum albumin as the standard.

Scanning electron microscopy. Some of the disordered and $\mathrm{N}$ juice vesicles isolated from fruit stored at $21 \mathrm{C}$ for 40 days were prefixed in $2 \%$ glutaraldehyde in Na-phosphate $(100 \mathrm{~mm}$, $\mathrm{pH} 7.2$ ) for $2 \mathrm{hr}$ and postfixed in $2 \%$ osmium tetroxide in the same buffer. Specimens were washed with DI water for $2 \mathrm{hr}$, dehydrated using an ethanol series, and $\mathrm{CO}_{2}$ in a critical-point dryer (Ladd Industry, Burlington, Vt.). Specimens were razor blade-fractured, mounted, sputter-coated with $\mathrm{Au}$, and examined with a Hitachi scanning electron microscope (S-530) at 20 $\mathrm{kV}$ of accelerating voltage.

\section{Results and Discussion}

Fresh weight, dry weight, and ethanol-soluble solids of grapefruit juice vesicles. The fresh weight (FW) of $\mathrm{G}$ vesicles was $60 \%$ greater than that of $\mathrm{N}$ vesicles (Table 1), which is in agreement with previous reports (Bartholomew et al., 1941; Sinclair and Jolliffe, 1961). Bartholomew et al. (1941) proposed that the size increase in $G$ resulted from new growth of the affected vesicles. Whether the size of $G$ vesicles is due to inherently large vesicles developing $G$ or new growth during $G$ development is not clear. $\mathrm{G}$ vesicles contained more dry matter (dry weight, DW) per vesicle than the $\mathrm{N}$ but DW on a per-gram FW basis was less. This observation indicates a reduced tissue density of $\mathrm{G}$ vesicles compared to $\mathrm{N}$ vesicles, as was also ob- served in $G$ vesicles from oranges (Chakrawar and Singh, 1977a). The FW and DW, on a per-vesicle basis, were lower in VC than in $\mathrm{N}$ vesicles (Table 1). VC vesicles were severely shriveled at later stages. These symptoms are similar to those observed in vesicles affected by dry juice sac or core dryness (Bartholomew et al., 1941; Matsumoto, 1964; Noort, 1969).

Ethanol-soluble solids were higher in $\mathrm{G}$ and VC than in $\mathrm{N}$ vesicles on a per-gram FW basis. However, on a per-vesicle basis, a higher EIS content was observed for $\mathrm{G}$ vesicles (163\%), whereas VC vesicles had only 570 more EIS than $\mathrm{N}$ vesicles, which was less than the standard deviations (Table 1). Sinclair and Jolliffe (1961) suggested that vesicles might produce more cell-wall material during the development of G. That EIS content did not change significantly in VC per vesicle indicates that the physiological events occurring in $\mathrm{G}$ vesicles did not occur in VC vesicles.

Polysaccharide composition of EIS from grapefruit tissue. Analysis of structural polysaccharides recovered from EIS revealed marked differences between the disorder types (Table 2). On a per-milligram EIS basis, there were slight or no differences in total pectin content between $\mathrm{N}$ and the disordered vesicles; however, on a per-vesicle basis, $\mathrm{G}$ vesicles had 2.5 times more total pectin content than $\mathrm{N}$ vesicles. For pectins, only WSP differed in VC vesicles compared to N. On either an EIS or vesicle basis, WSP decreased $45 \%$.

In $\mathrm{G}$ compared to $\mathrm{N}$ vesicles, both WSP and CSP were higher on a per-vesicle basis, but lower on an EIS basis. Note that considerable difference in WSP and some difference in CSP content occurred between visually $\mathrm{N}$ vesicles isolated from fruit containing the respective disordered vesicles. Visually normal vesicles from $\mathrm{G}$ and $\mathrm{VC}$ fruit contained $27.8 \mu \mathrm{g}$ and $17.6 \mu \mathrm{g}$ WSP per vesicle, respectively. This observation and the slight difference in CSP indicate that the visually $\mathrm{N}$ vesicles were probably beginning to develop symptoms of the vesicle disorders. More soluble pectins may be the first wall components to change in disordered vesicles. Even so, WSP constituted a minor component (1\% to $3 \%$ ) of the EIS and the contents of other polysaccharides examined in the visually $\mathrm{N}$ vesicles from $\mathrm{VC}$ and $G$ fruit were similar, providing evidence that the normalappearing vesicles were still more like completely healthy vesicles than disordered vesicles, and, therefore, served as reasonable comparisons. Our recent work (unpublished data) indicates that the wall component changes occur very rapidly when they start.

Hemicellulose content on an EIS basis was lower in $G$ than

Table 1. Juice-vesicle fresh weight (FW), dry weight (DW), and ethanol-insoluble solids content (EIS) of normal and disordered vesicles of 'Marsh Seedless' grapefruit.

\begin{tabular}{|c|c|c|c|c|c|c|c|c|c|c|}
\hline & \multicolumn{10}{|c|}{ Disorder $^{2, y}$} \\
\hline & \multicolumn{5}{|c|}{ Granulation } & \multicolumn{5}{|c|}{ Vesicle collapse } \\
\hline & \multicolumn{2}{|c|}{ Normal } & \multicolumn{3}{|c|}{ Granulated } & \multicolumn{2}{|c|}{ Normal } & \multicolumn{3}{|c|}{ Collapsed } \\
\hline & $\mathrm{mg} \cdot \mathrm{g}^{-1} \mathrm{FW}$ & $\overline{\mathrm{mg} / \mathrm{vesicle}}$ & $\mathrm{mg} \cdot \mathrm{g}^{-1} \mathrm{FW}$ & $\mathrm{mg} /$ vesicle & $\%$ change & $\mathrm{mg} \cdot \mathrm{g}^{-1} \mathrm{FW}$ & mg/vesicle & $\mathrm{mg} \cdot \mathrm{g}^{-1} \mathrm{FW}$ & $\mathrm{mg} /$ vesicle & $\%$ change \\
\hline \multirow{2}{*}{\multicolumn{11}{|c|}{ Component $=$}} \\
\hline & & $107 \pm 8.9$ & & $174 \pm 13.5$ & 61.7 & & $104 \pm 7.2$ & & $46.3 \pm 1.4$ & -55.6 \\
\hline DW & $118 \pm 5.3$ & 11.9 & $83.6 \pm 3.0$ & 14.5 & 21.8 & $119 \pm 3.1$ & 12.4 & $113 \pm 5.6$ & $5 . \overline{2}$ & -58 \\
\hline EIS & $8.2 \pm 0.3$ & 0.89 & $13.5 \pm 0.8$ & 2.34 & 163 & $8.8 \pm 0.3$ & 0.92 & $20.9 \pm 0.6$ & 0.97 & 5 \\
\hline
\end{tabular}

${ }^{\mathrm{z}}$ Values are the average of three replications $\pm S D(50$ vesicles per replication for DW and FW). Values per vesicle are calculated from freshweight content and fresh weight per vesicle.

yPercentage change from apparently normal vesicle value. 
Table 2. Comparisons of juice-vesicle cell wall components between normal and disordered tissue of 'Marsh Seedless' grapefruit.

\begin{tabular}{|c|c|c|c|c|c|c|c|c|c|c|c|}
\hline \multicolumn{12}{|c|}{ Disorder } \\
\hline \multicolumn{6}{|c|}{ Granulation } & \multicolumn{6}{|c|}{ Vesicle collapse } \\
\hline \multicolumn{2}{|l|}{ Normal } & \multicolumn{4}{|c|}{ Granulated } & \multicolumn{3}{|c|}{ Normal } & \multicolumn{3}{|c|}{ Collapsed } \\
\hline $\begin{array}{l}\mu g \text { sugars } \\
\text { per mg EIS }\end{array}$ & $\begin{array}{l}\mu g \text { sugars } \\
\text { per vesicle }\end{array}$ & $\begin{array}{l}\mu g \text { sug } \\
\text { per mg }\end{array}$ & $\begin{array}{l}\text { gars } \\
\text { EIS }\end{array}$ & $\begin{array}{l}\mu \mathrm{g} \text { sugars } \\
\text { per vesicle }\end{array}$ & $\begin{array}{c}\% \\
\text { change }\end{array}$ & $\begin{array}{l}\mu g s \\
\text { per } m\end{array}$ & $\begin{array}{l}\text { sugars } \\
\text { ng EIS }\end{array}$ & $\begin{array}{l}\mu g \text { sugars } \\
\text { per vesicle }\end{array}$ & $\begin{array}{c}\mu \mathrm{g} \text { sugars } \\
\text { per mg EIS }\end{array}$ & $\begin{array}{l}\mu g \text { sugars } \\
\text { per vesicle }\end{array}$ & $\begin{array}{c}\% \\
\text { change }^{\mathrm{z}}\end{array}$ \\
\hline \multicolumn{12}{|l|}{ Pectins ${ }^{y}$} \\
\hline TP $\quad 375 \pm 12.1$ & 334 & $354 \pm$ & 7.0 & 829 & 148 & 349 & \pm 3.9 & 321 & \pm 3.4 & 340 & 6 \\
\hline WSP $31.2 \pm 1.7$ & 27.8 & $26.8 \pm$ & 1.2 & 62.7 & 126 & 19.1 & \pm 0.8 & 17.6 & $10.0 \pm 0.7$ & 9.7 & -45 \\
\hline CSP $116 \pm 8.7$ & 103 & $82.6 \pm$ & 2.3 & 193 & 88 & 130 & \pm 1.4 & 120 & $135 \pm 3.7$ & 131 & 9 \\
\hline \multicolumn{12}{|l|}{ Hemicellulose } \\
\hline $111 \pm 3.9$ & 98.7 & $87.0 \pm$ & 2.6 & 203 & 106 & 103 & \pm 3.2 & 95.0 & $97.9 \pm 1.9$ & 94.2 & -1 \\
\hline \multicolumn{12}{|l|}{ Cellulose } \\
\hline $134 \pm 11.6$ & 119 & $142 \pm$ & 19.2 & 332 & 179 & 121 & \pm 11.2 & 111 & $111 \pm 3.6$ & 108 & -3 \\
\hline
\end{tabular}

zPercentage change from normal vesicle value.

yTP, total pectins; WSP, water-soluble pectins; CSP, chelator-soluble pectins. Numbers are the average of three replications \pm SD ( 50 vesicles per replication for DW and FW). Values per vesicle are calculated from content per EIS and EIS per vesicle.
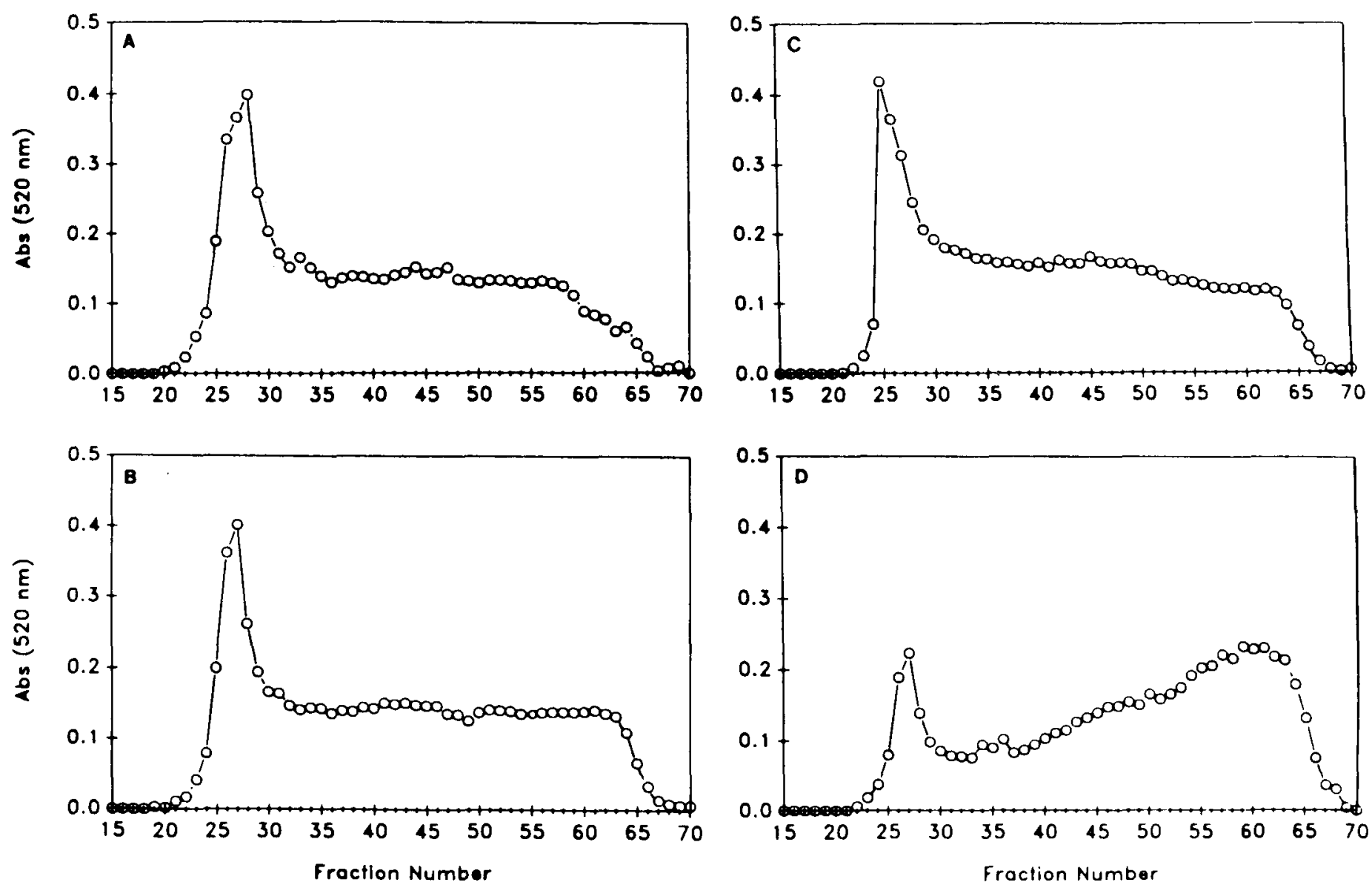

Fig. 1. Gel-filtration profiles of water-soluble pectins from normal-appearing and disordered vesicles of 'Marsh Seedless' grapefruit. Decreasing molecular weight occurs with increasing fraction number. (A) Pectins from normal (N) vesicles from granulated (G) fruit; (B) pectins from $\mathrm{G}$ vesicles; (C) pectins from $\mathrm{N}$ vesicles from fruit with collapsed vesicle (VC); (D) pectins from VC.

in $\mathrm{N}$ vesicles; however, on a per-vesicle basis, hemicellulose content increased 2-fold (Table 2). The hemicellulose contents for $\mathrm{N}$ and $\mathrm{VC}$ vesicles were similar.

Cellulose content did not change in either disorder type on an EIS basis, but was nearly three times higher in $\mathrm{G}$ than in $\mathrm{N}$ vesicles (Table 2). On a per-vesicle basis, $G$ vesicles contained
1.8 to 2.5 times more structural polysaccharides (pectins, hemicellulose, and cellulose) than did $\mathrm{N}$ vesicles (Table 2). Although cell wall components were not always greater in $\mathrm{G}$ vesicles on an EIS basis, they were significantly greater on a FW basis than in $\mathrm{N}$ vesicles. These results suggest that $\mathrm{G}$ is associated with an anomalous increase in cell-wall synthesis and/or changes 
in cell-wall turnover rate at the latter stages of fruit development. Differences in structural polysaccharide content were not observed in VC, although some qualitative changes were observed, particularly the decrease in WSP.

Chromatography of pectins and hemicelluloses. The gel-filtration elution patterns of WSP from N and G vesicles were similar (Fig. $1 \mathrm{~A}$ and $\mathrm{B}$ ); whereas the profile of the VC WSP exhibited a markedly lower void component and a relatively greater quantity of smaller $\mathrm{M}_{\mathrm{r}}$ pectins fractionating on the gel (Fig. ID) when compared to the $\mathrm{N}$ vesicle profile (Fig. IC). The $\mathrm{N}$ vesicle isolates were nearly identical (Fig. $1 \mathrm{~A}$ and $\mathrm{C}$ ). These results are further evidence for WSP modification in VC.

The elution behavior of CSP was essentially similar to that of WSP, with the exception that the void peaks were more pronounced (Fig. 2). As with the WSP, disorder-associated changes were most pronounced in $\mathrm{VC}$ vesicles that yielded a more heterogeneous (in terms of $\mathrm{M}_{\mathrm{r}}$ ) population of CSP (Fig. 2D). Since the combined pectins in WSP and CSP comprised $=40 \%$ of the total pectins, the data obtained from gel chromatography indicate that 1) $\mathrm{G}$ vesicles contained pectins unaltered in terms of their $\mathrm{M}_{\mathrm{r}}$, and 2) pectin degradation might be a potential factor involved in the collapse of vesicles in $\mathrm{VC}$ or a secondary result from cellular breakdown.

Polygalacturonase (endo-PG) is temporally associated with softening and pectin changes in many fruit types (Brady, 1987; Huber, 1983a). In citrus, only very low levels of exo-PG have been reported in the fruit (Riov, 1974). In the present study, endo-PG activity was not detected in either $\mathrm{N}$ or disordered vesicles (data not shown). Although exo-PG may be present, exo-PG alone is unable to degrade polymeric pectins (Reese, 1977). The alternative explanation for these pectin changes in $\mathrm{VC}$ vesicles is non-PG-mediated modification. Low-molecular weight pectins appear during fruit ripening, at least in muskmelons, which also contain no endo-PG (McCollum, 1987). We suggest the possibility that there is release of pectins during turnover of hemicelluloses, but the factors causing this change are unknown.

Hemicelluloses extracted from $\mathrm{G}$ and $\mathrm{VC}$ vesicles and their respective, adjacent $\mathrm{N}$ control vesicles exhibited similar elution patterns on Ultrogel 34 (data not shown). The proportion of large- $M_{r}$, hemicelluloses was slightly higher in $G$ than in $N$ vesicles. The hemicellulose profiles indicate that slight modification of $\mathrm{M}_{\mathrm{r}}$ may occur; however, if cell-wall degradation is involved in $\mathrm{VC}$, pectin degradation is probably of more importance. Although the hemicelluloses may be of little importance in these disorders, the $\mathrm{M}_{\mathrm{r}}$ distributions of all samples examined were remarkably similar to those observed for ripe tomato (Huber, 1983b), strawberry (Huber, 1984), and hot pepper (Grosset al., 1986) fruit. Ion exchange fractionation against a $\mathrm{NaCl}$ gradient did not indicate any differences in WSP, CSP, or hemicelluloses between VC, G, or $\mathrm{N}$ vesicles (data not shown).

Neutral sugar composition of pectins and hemicelluloses. Total neutral-sugar content of WSP was $87 \%$ higher in G and $16 \%$ higher in $\mathrm{VC}$ than in $\mathrm{N}$ vesicles (Table 3). There were higher levels of all neutral sugars associated with WSP from G, particularly arabinose and galactose, the two major neutral sugars
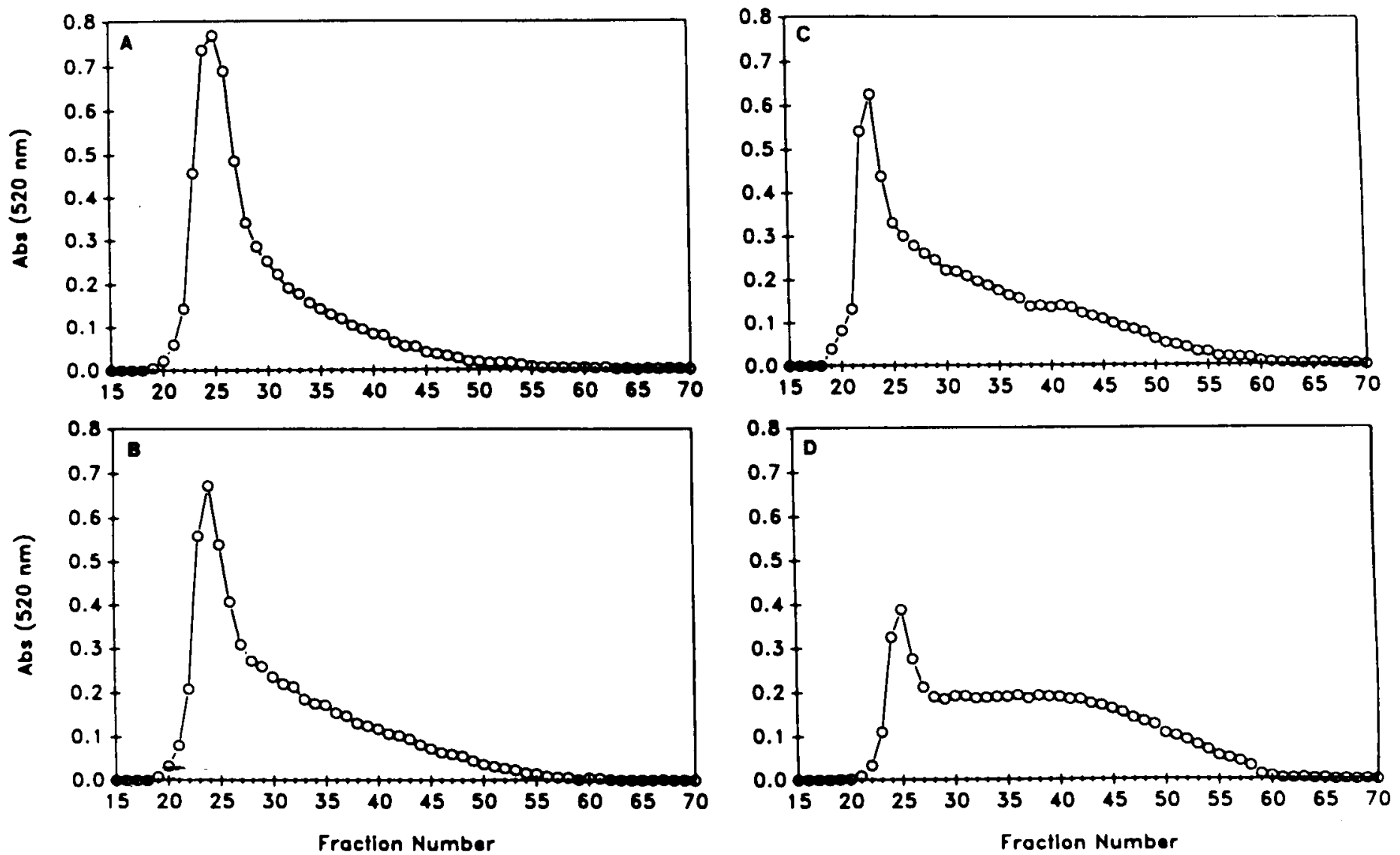

Fig. 2. Gel-filtration profiles of chelator-soluble pectins from normal-appearing and disordered vesicles of 'Marsh Seedless' grapefruit. Decreasing molecular weight occurs with increasing fraction number. (A) Pectins from normal (N) vesicles from granulated (G) fruit; (B) pectins from $\mathrm{G}$ vesicles; (C) pectins from $\mathrm{N}$ vesicles from fruit with collapsed vesicles (VC); (D) pectins from VC.

J. Amer. Soc. Hort. Sci. 115(2):281-287. 1990. 
Table 3. Neutral sugars in water-soluble pectins from normal and disordered juice vesicles of 'Marsh Seedless' grapefruit.

Disorder ${ }^{2, y}$

\begin{tabular}{lccccc} 
& \multicolumn{2}{c}{ Granulation } & & \multicolumn{2}{c}{ Vesicle collapse } \\
\cline { 2 - 3 } \cline { 5 - 6 } Neutral & Normal & Granulated & & Normal & Collapsed \\
\multicolumn{1}{r}{ mol } & Noutral/uronic & acid sugars & in & water-soluble pectins \\
Rhamnose & 0.3 & 1.5 & & 2.0 & 1.0 \\
Fucose & 0.4 & 0.7 & & 1.6 & tr \\
Arabinose & $10.3 \pm 0.2$ & $13.9 \pm 0.2$ & & $16.9 \pm 0.4$ & $23.6 \pm 1.2$ \\
Xylose & tr & 1.4 & & 4.0 & 2.1 \\
Mannose & tr & 0.7 & & 1.2 & 0.4 \\
Galactose & $4.2 \pm 0.1$ & $10.0 \pm 0.3$ & & $9.0 \pm 1.0$ & $13.3 \pm 0.8$ \\
Glucose & nd & 0.3 & & tr & tr \\
Total & 15.2 & 28.5 & & 34.7 & 40.4
\end{tabular}

${ }^{2}$ Values are the average of two replications with two chromatographic injections per replication $\pm S D$.

$y_{\text {nd }}$ and $t r$ indicate nondetectable and trace, respectively.

Table 4. Sugars composition of hemicelluloses from normal and disordered juice vesicles of 'Marsh Seedless' grapefruit.

\begin{tabular}{|c|c|c|c|c|}
\hline \multirow{3}{*}{$\begin{array}{l}\text { Neutral } \\
\text { sugars }\end{array}$} & \multicolumn{4}{|c|}{ Disorder $^{z}$} \\
\hline & \multicolumn{2}{|c|}{ Granulation } & \multicolumn{2}{|c|}{ Vesicle collapse } \\
\hline & Normal & Granulated & Normal & Collapsed \\
\hline & \multicolumn{4}{|c|}{$\% \mathrm{~mol}$} \\
\hline Rhamnose $^{y}$ & $\operatorname{tr}$ & $\operatorname{tr}$ & $\operatorname{tr}$ & nd \\
\hline Fucose & $1.7 \pm 0.3$ & $2.9 \pm 0.6$ & $2.4 \pm 0.9$ & $1.6 \pm 0.8$ \\
\hline Arabinose & $10.2 \pm 1.4$ & $7.3 \pm 0.7$ & $11.5 \pm 0.4$ & $7.9 \pm 0.2$ \\
\hline Xylose & $59.9 \pm 0.4$ & $55.7 \pm 2.9$ & $56.5 \pm 4.2$ & $60.4 \pm 1.2$ \\
\hline Mannose & $8.0 \pm 0.1$ & $9.9 \pm 1.3$ & $9.0 \pm 1.3$ & $11.1 \pm 0.8$ \\
\hline Galactose & $7.5 \pm 1.0$ & $8.3 \pm 0.9$ & $9.0 \pm 1.2$ & $6.8 \pm 1.1$ \\
\hline Glucose & $12.5 \pm 0.6$ & $15.9 \pm 1.4$ & $11.5 \pm 0.6$ & $12.3 \pm 0.5$ \\
\hline
\end{tabular}

${ }^{2}$ Values are the average of two replications with two injections per replication $\pm \mathrm{SD}$.

$y_{\text {tr }}$ and nd indicate trace and nondetectable, respectively.

in the WSP. Collapsed vesicles showed similar trends, but arabinose and galactose were present at still higher levels, even in apparently $\mathrm{N}$ vesicles, than in corresponding $\mathrm{N}$ and disordered vesicles from $G$ fruit. This result again suggests that the normal-appearing vesicles in $\mathrm{VC}$ fruit were beginning to change and that pectin modification may be the first wall component affected. Pectins derived from vesicles in VC fruit contained about two times more neutral sugar than vesicles from $G$ fruit. Chelator-soluble pectins from both $\mathrm{N}$ and disordered vesicles were extremely low in neutral sugars, 0.4 to $1.3 \mathrm{~mol}$ percent total neutral sugars (data not shown). By what mechanism neutral sugars in WSP increased in both disordered vesicles (VC and G) is not known. Gross (1986) reported that some watersoluble, ethanol-insoluble neutral sugars increased along with galacturonic acid during ripening of tomatoes. Thus, the increase in neutral sugars in disordered tissue may be an expression of tissue senescence. In $\mathrm{N}$ vesicles, the major sugars in hemicelluloses were xylose, glucose, and arabinose, in decreasing order (Table 4). Mannose was the third most prevalent sugar in disordered "vesicles. Major compositional differences in hemicellulose sugars were not detected between $\mathrm{N}$ and disordered vesicles, although arabinose levels appeared to be significantly lower in disordered vesicles compared to the $\mathrm{N}$ vesicles.

Scanning electron microscopy (SEM) disclosed significant differences between $\mathrm{N}, \mathrm{G}$, and $\mathrm{VC}$ vesicles. The micrographs

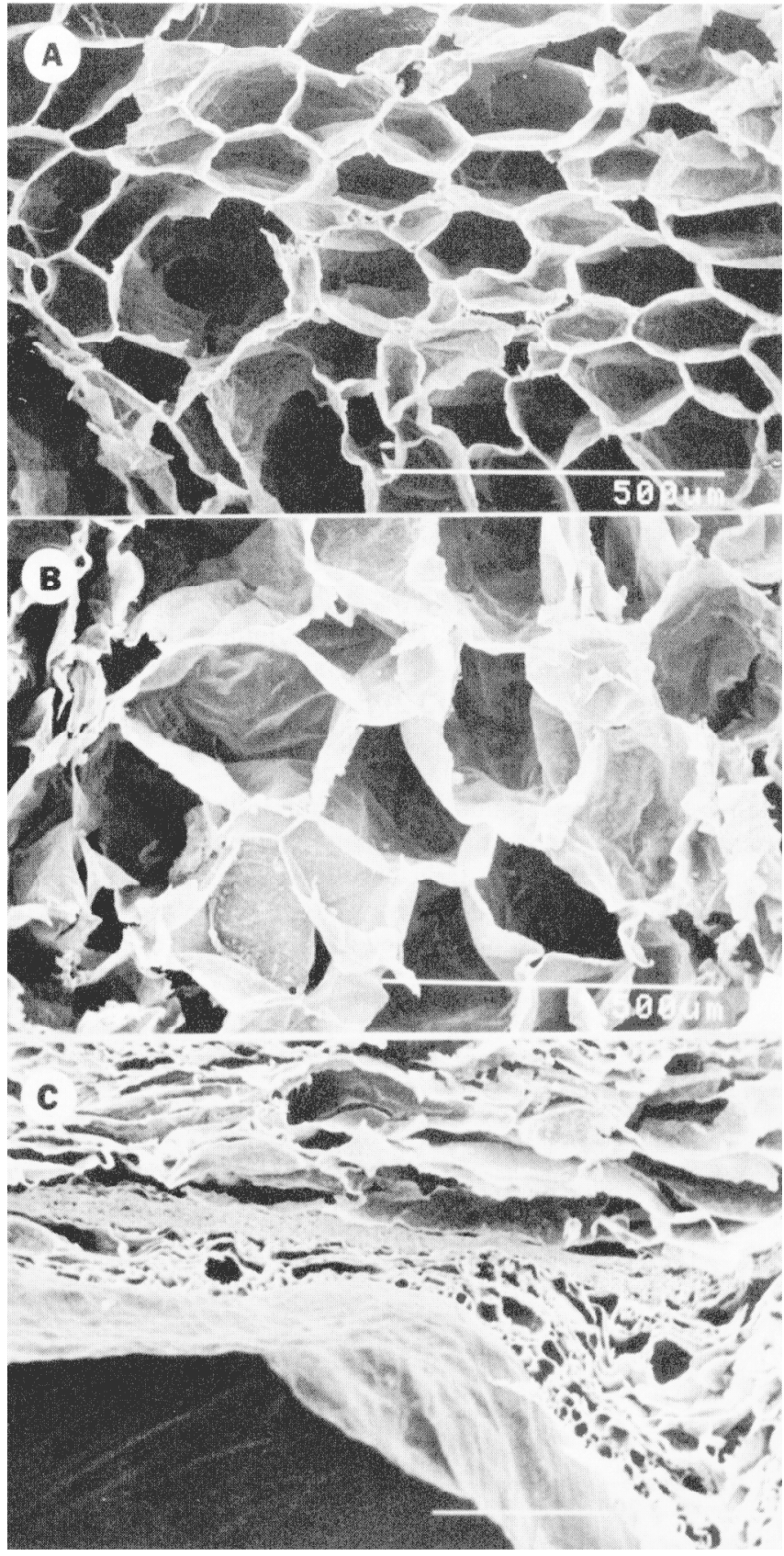

Fig. 3. Scanning electron micrographs of inner juice cells of 'Marsh Seedless' grapefruit juice vesicles with different vesicle disorders. (A) Normal vesicle; (B) granulated vesicle; (C) vesicle collapse.

were taken of the inner parenchymatous juice cells (Fig. 3). Healthy vesicles (Fig. 3A) had noticeably smaller juice cells than in $\mathrm{G}$ vesicles (Fig. 3B). In VC, most of the cells were partially or completely collapsed, resulting in stacked layers of cell walls (Fig. 3C). The lack of major changes in cell wall components of $\mathrm{VC}$ vs. $\mathrm{N}$ vesicles, along with the cell collapse, suggests that $\mathrm{VC}$ is a relatively rapid cell death phenomenon.

The greater size of cells in $\mathrm{G}$ has been proposed to result from new growth of the affected vesicles (Bartholomew et al., 1941; Matsumoto, 1964). Whether the size increase in $G$ juice cells is due to originally large vesicles developing this disorder or new growth of cells during granulation is unknown. Juice vesicles at the stem end and stylar end are generally larger than 
those in the central portion (Matsumoto, 1964). In the present study, fresh and dry weights increasedonly $60 \%$ and $22 \%$, respectively, in $\mathrm{G}$ vesicles, whereas EIS increased $>150 \%$ on a per- $G$ vesicle basis. This result can reinterpreted as evidence of new synthesis in $\mathrm{G}$ vesicles, especially pectins, cellulose, and probably lignin (Shomer et al., 1989), all of which may contribute to the increase of juice-cell size, as new wall synthesis, if wall structural component bonding release mechanisms also operate (Bolwell, 1988). Lignin was readily detected histochemically by phloroglucinol and toluidine blue in $\mathrm{G}$ vesicles, whereas $\mathrm{N}$ vesicles seldom showed positive staining for lignins (Burns and Achor, 1989). We also treated EIS with phloroglucinol, and positive lignin staining occurred only in $G$ vesicles. Uneven cell-wall thickening, especially in hyperdermal cells, in $\mathrm{G}$ vesicles has been found in oranges (Bartholomew et al., 1941; Matsumoto, 1964), in partially collapsed grapefruit vesicles (Bums and Achor, 1989) and in pummelo (Shomer et al., 1989), but the marked changes in cell-wall thickness were not observed in epidermal or hypodermal cells in our study using SEM. About $40 \%$ of the EIS is unaccounted for by the structural polysaccharides measured. Proteins and pectic neutral sugars may account for most of this additional EIS in $\mathrm{N}$ and VC, since starch is not present in citrus vesicles (Gebhardt et al., 1982). Lignin is implicated in the large increase $(>150 \%$ ) of EIS per-G vesicle (Shomer et al., 1989). Protein was not elevated in pummelo (Shomer et al., 1989). In future work, lignin and protein contents of the EIS should be quantified.

The differences in wall components measured in this study indicate that, in grapefruit, G and VC of juice vesicles are different phenomena and not stages of the same disorder or senescence process, even though $G$ vesicles partially collapse in the final stages of this disorder (Bartholomew et al., 1941).

\section{Literature Cited}

Ahmed, A.E. and J.M. Labavitch. 1977. Cell wall metabolism in ripening fruit: I. Cell wall changes in ripening 'Bartlett' pears. Plant Physiol. 65:1009-1013.

Albrigo, L. G., K. Kawata, P.W. Hale, J.J. Smoot, and T.T. Hatton, Jr. 1980. Effect of harvest date and preharvest treatment on Florida grapefruit condition in export to Japan. Proc. Fla. State Hort. Sot. 93:323-327.

Awasthi, R.D. and J.P. Nauriyal. 1972. Studies on granulation in sweet orange (Citrus sinensis Osbeck): II. Effect of age, tree condition, tree aspect, fruit size, rootstock, and tree variation on granulation. J. Res. Punjab Agr. Univ. 10(1):62-70.

Bartholomew, E. T., W.B. Sinclair, and F.M. Turrell. 1941. Granulation of 'Valencia' oranges. Univ. Calif. Agr. Expt. Sta. Bul. 647.

Blumenkrantz, N. and G. Asboe-Hanson. 1973. New method for quantitative determination of uronic acids. Anal. Biochem. 54:484-489.

Bolwell, G.P. 1988. Synthesis of cell wall components: Aspects of control. Photochemistry 27:1235-1253.

Brady, C.J. 1987. Fruit ripening. Annu. Rev. Plant Physiol. 23:155174.

Brafford, M.M. 1976, A rapid and sensitive method for the quantitation of microgram quantities of protein utilizing the principle of proteindye binding. Anal. Biochem. 72:248-254.

Burns, J.K. and D.S. Achor. 1989. Cell wall changes in juice vesicles associated with "section drying" in stored late-harvested grapefruit. J. Amer. Soc. Hort. Sci. 114(2):283-287.

Chakrawar, V.R. and R. Singh. 1977a. Studies on citrus granulation: I. Physical and quality aspects of granulation. Haryana J. Hort. Sci. 6(3-4ol5-1):1L5-1j1.

Chakrawar, V.R. and R. Singh. 1977b. Studies on citrus granulation: 11. Physiological and biochemical aspects of granulation. Haryana J. Hort. Sci. 6(3-4):132-135.

E1-Zeftawi, B. M. 173. Granulation of 'Valencia' oranges. Food Technol. Austral. 25: 103-107.

E1-Zeftawi, B.M. 1978. Factors affecting granulation and quality of late-picked 'Valencia' orange. J. Hort. Sci. 53:331-337.

Gebhardt, S. E., R. Cutrufelli, and R.H. Matthews. 1982. Composition of foods: Fruits and fruit juices raw, processed, prepared. USDA Hdbk. 8-9.

Gilfillan, I.M. and J.A. Stevenson. 1977. Postharvest development of granulation in South African export oranges. Proc. Intl. Soc. CitriCult. 1:299-303.

Gross, K.C. 1986. Composition of ethanol-insoluble polysaccharides in water extracts of ripening tomatoes. Photochemistry 25:373-376.

Gross, K. C., D.E. Watnda, M.S. Kong, S.D. Kim, K.S. Kim, and S.W. Lee. 1986. Biochemical changes associated with the ripening of hot pepper fruit. Physiol. Plant. 66:31-36.

Hedge, J.E. and B.T. Hofreiter. 1962. Determination of reducing sugars and carbohydrates. Methods in carbohydrate chemistry. vol. I. Analysis and preparation of sugars. Academic, New York. p. 380398.

Huber, D.J. 1983a. The role of cell wall hydrolyses in fruit softening. Hort. Rev. 5:169-219.

Huber, D.J. 1983b. Polyuronide degradation and hemicellulose modification in ripening tomato fruit. J. Amer. Sot. Hort. Sci. 108:405409.

Huber, D.J. 1984. Strawberry fruit softening: The potential roles of poluronides and hemicelluloses. J. Food Sci. 49:1310-1315.

Hwang, Y-S., L.G. Albrigo, and D.J. Huber. 1988. Juice vesicle disorders and in-fruit seed germination in grapefruit. Proc. Fla. State Hort. Sot. 101:161-165.

Loescher, W. and D.J. Nevins. 1972. Auxin-induced changes in Avena coleoptile cell wall composition. Plant Physiol. 50:556-559.

Matsumoto, K. 1964. Studies on granulation of late-maturing oranges, especially as exemplified in the Sanbokan variety. Memoirs of the Ehime Univ. Japan Section. IV. Agriculture no. 10.

McCollum, T.G. 1987. Metabolism of soluble and structural carbohydrates during muskmelon fruit development. PhD Diss. Univ. of Florida, Gainesville.

Noort, G.V. 1969. Dryness in naval fruit. Proc. 1st Intl. Cit. Symp. 3:1333-1342.

Reese, E.T. 1977. Degradation of polymeric carbohydrates by microbial enzymes, p. 311-367. In: F.A. Loewus and V.C. Rurreckles (eds.). Recent advances in photochemistry. vol. H. Plenum, New York.

Riov, J. 1974. A research note: Polygalacturonase activity in citrus fruit. J. Food Sci. 40:201-202.

Shomer, I., E. Chalutz, R. Vasiliver, E. Lomaniec, and M. Berman 1989. Sclerification of juice sacs in pummelo (Citrus gramdis) fruit. Can. J. Bot 67:625-632.

Sinclair, W.B. and V.A. Jolliffe. 1961. Chemical changes in the juice vesicles of granulated 'Valencia' oranges. J. Food Sci. 26:276-282.

Updegraff, D.M. 1969. Semimicro determination of cellulose in biological materials. Anal. Biochem. 32:420-424. 